\title{
Multicultural Education through Constructivist Learning Strategies
}

\author{
Ahmad Saefudin', Ro'fah'2, Dyah Arum Sari ${ }^{3}$ \\ 1 Universitas Islam Nahdlatul Ulama Jepara, Indonesia \\ ${ }^{2}$ Universitas Islam Negeri (UIN) Sunan Kalijaga Yogyakarta, Indonesia \\ 3 Universitas Islam Nahdlatul Ulama Jepara, Indonesia
}

ahmadsaefudin@unisnu.ac.id

\begin{tabular}{|c|c|}
\hline \multirow{3}{*}{$\begin{array}{l}\text { ARTICLE INFO } \\
\text { Article history: } \\
\text { Received } \\
\text { February 03, } 2021 \\
\text { Revised } \\
\text { June 08, } 2021 \\
\text { Accepted } \\
\text { July 12, } 2021\end{array}$} & ABSTRACT \\
\hline & $\begin{array}{l}\text { The Madrasa as Islamic educational institutions has a crucial role in } \\
\text { promoting multicultural education values so that students avoid } \\
\text { prejudice, suspicion, and intolerance. The Akidah Akhlak Teachers at MI } \\
\text { Masalikil Huda } 2 \text { have a unique way to promote these values, namely } \\
\text { through constructivism-based learning strategies. With a qualitative } \\
\text { approach relying on the interview, observation, and documentation } \\
\text { techniques, the researchers try to answer two important questions; how } \\
\text { the teacher's strategy in introducing students to the values of } \\
\text { multicultural education and what approaches they use in the learning } \\
\text { process in the classroom. Finally, this research concludes that teachers } \\
\text { instill the values of democracy, tolerance, equality or equality, } \\
\text { brotherhood or kinship, and the value of unity in learning Akidah } \\
\text { Akhlak. There are four constructivism strategies in the delivery of } \\
\text { multicultural education, namely cooperative learning, conceptual } \\
\text { achievement, exemplary, habituation, and role-playing. They also rely on } \\
\text { historical approaches, gender perspective approaches, and aesthetic } \\
\text { approaches. Thus, the claim that the madrasa is inconsistent in delivering } \\
\text { Islamic religious material with a multicultural perspective is refuted by } \\
\text { the findings of this research. }\end{array}$ \\
\hline & $\begin{array}{l}\text { Keywords: Multicultural Education, Constructivism Learning Strategies, } \\
\text { Cooperative Learning. }\end{array}$ \\
\hline How to cite & $\begin{array}{l}\text { Saefudin, A., Ro'fah, R., \& Sari, D. (2021). Multicultural Education through } \\
\text { Constructivist Learning Strategies. Jurnal Iqra' : Kajian Ilmu Pendidikan, 6(2). 13- } \\
\text { 26. https://doi.org/10.25217/ji.v6i2.1399 }\end{array}$ \\
\hline $\begin{array}{l}\text { ournal Homepage } \\
\text { his is an open acce }\end{array}$ & $\begin{array}{l}\text { http://journal.iaimnumetrolampung.ac.id/index.php/ji/ } \\
\text { rticle under the CC BY SA license } \\
\text { https://creativecommons.org/licenses/by-sa/4.0/ }\end{array}$ \\
\hline
\end{tabular}

\section{INTRODUCTION}

The practice of multicultural education in school institutions in Indonesia is accused by some observers of being inconsistent. Teachers are considered inadequate in introducing pluralism, tolerance, democracy, citizenship, and brotherhood (Raihani, 2018). Even though, the commitment of school institutions plays a vital role in promoting inclusive religious teachings and strives to change the attitudes of students to avoid a biased, prejudiced viewpoint, and overshadowed by suspicion of other groups. (Saeed, 1999; Sahlan, 2014). Moreover, the pluralistic culture of Indonesian society requires teachers to make pedagogical innovations through various designs of cooperative learning models (Zulaeha, 2013).

It is quite different from the citizenship politics in the United States which gives privileges to certain tribes before the State-for example, Indians are recognized as 
"domestic independent nations" who have the right to govern themselves, Puerto Rico is labeled as a "commonwealth", and Guam is made a protectorate (Kymlicka, 1995, p. 12), ethnic groups in Indonesia, whose number is not less than 316 (Maryati, 2006, p. 11) be in an equal position before the constitution under the framework of Pancasila (Ismail, 1995). Even though the regional autonomy policy took effect after the Suharto regime collapsed in 1999, it does not mean that the Indonesian government gave special rights to certain ethnic groups (Seymour \& Turner, 2002). This is where the cultivation of multicultural political awareness in a democratic era finds its urgency. Because, like a double-edged sword, the diversity of a nation holds irony. On the one hand, it has a positive impact, namely showing that Indonesia has a wealth of diverse cultural treasures. On the other hand, it has a negative impact, because sometimes diversity can trigger conflict between groups, whether in the name of religion, race, ethnicity, and so on. The multicultural education paradigm is expected to answer this dilemma by teaching the ethos of respecting differences (Jiyanto \& Efendi, 2016).

Madrasah Ibtidaiyah (MI) Masalikil Huda 2 was chosen to be the research locus in this study because this Islamic education institution in Jepara Regency promotes the values of multicultural education through learning Akidah Akhlak. The teacher invites students to understand issues of democracy, tolerance, equality, brotherhood, and unity. As explained by one teacher, Ibu Rofi'atun, to the researcher, "Children can appreciate the diversity that exists in all components of the school, such as students, teachers, and others. So it needs to be introduced to the value of multicultural education in learning Akidah Akhlak, for example, democracy, tolerance, unity, harmony, and compassion," (the results of the interview with Rofi'atun, Akidah Akhlak Teacher, 22 August 2020). Outside the classroom, school culture also introduces the spirit of brotherhood as an integral part of multicultural education. As the Head of the madrasa, Sri Handayani said below: "To develop empathy for children, we usually teach them to visit friends who are sick. Accompanied by a teacher or homeroom teacher, they usually take funds from the class treasury. We continue to train these habits to foster an attitude of affection, empathy, and a sense of brotherhood" (interview with Sri Handayani, Head of MI Masalikil Huda 2, 19 August 2020).

This article attempts to answer two crucial questions as academic problems. First, what is the teacher's strategy of introducing students to the values of multicultural education? Second, what approaches do they use in the learning process in the classroom? As a theoretical basis, I borrow the thesis popularized by Jean Piaget on constructivist learning theory (Piaget, 2013, 2003; Piaget, J., \& Valsinen, J. (2017). Knowledge is essentially actively constructed by a child through age-appropriate learning interactions (Csizmadia, Standl, \& Waite, 2019). The stage of child development, for Piaget, is divided into four, namely: 1) motor-sensory, 2) preoperational, 3) concrete operation and 4) formal operation. (Pritchard, 2008). Referring to the above stages, MI Masalikil Huda 2 students are included in the classification of the concrete operational phase. That is, their logic begins to be played to study multicultural education material inside and outside the classroom.

The study of multicultural education has long been in demand by scholars. From a political perspective, multicultural citizenship accommodates various forms of cultural pluralism. At this point, minority groups merge with the political community through a process of (Parekh, 2000; Soutphommasane, 2005; May, 2009; Kymlicka, 2020). From the pattern, we can map it into two models. First, multiculturalism arises through the melting of a small community into a large group that already has an established culture. This small group tries to survive as a separate community in the 
middle of the majority culture by demanding government autonomy. Second, multiculturalism was born from the immigration process of individuals and families. They gradually joined allied ethnic groups and were generally accepted by the larger group of society. They are reluctant to separate themselves through the establishment of an autonomous authority. But what is being fought for is changes in the dominant constitution and institutions to recognize the various cultures that exist in a country.

Multiculturalism is also often associated with the discourse of global society such as democracy, identity, human rights, and nationalism (Haddock \& Sutch, 2003; Kivisto, 2002; Máiz \& Requejo, 2004). Multiculturalism begins with an ethnic group that contains a group of people who accidentally share the same culture. It could also be argued that these ethnicities are descended from people who identify themselves and/or are identified by others as belonging to the same group. By carrying out the issue of unity as the basis for democratic stability, a collective sentiment emerges for dialogue with other ethnicities in a country. Each ethnic group receives recognition of differences and respect which ultimately forms an integral element of equal citizenship status.

This research is important to do to ward off accusations from some scholars who think that the function of the madrasa in Indonesia is changing. Along with the proliferation of post-1998 reform Islamic educational institutions, the madrasa, which have long been known as moderate Islamic institutions, tend to shift towards conservative and exclusive. Although there are not many, madrassas are alleged to provide facilities for militant Islamic groups to spread the doctrine of violence and acts of terror. (Noor, Sikand, \& Bruinessen, 2020). What some scholars believe is only casuistic and cannot be generalized, because most of the madrasa in Indonesia still teach a multicultural paradigm and an inclusive perspective for students. Not a few scholars also specifically discuss multiculturalism in the educational domain (DomNwachukwu, 2010; Grant \& L.Lei, 2001; Sahlan, 2014). The success of schools in solving diversity problems depends on the pedagogical competence of teachers in anchoring teaching and learning to students in the classroom. On a technical level, the development of multicultural-based teaching materials refers to the cognitive skills of teachers, views of cultural diversity, and accustoms to multicultural activities in schools.

If previous research has taken an interest in the topic of multiculturalism with a global political perspective on citizenship such as cultural pluralism, democracy, and human rights, and many highlight ethnic diversity as its main domain, this study offers a different frame of mind. It is no longer theoretical, researchers deliberately make the madrasa as research locations, and this has not been paid much attention to previous scholars, who automatically put the practice of applying multicultural values in a thick Islamic nuance. At this point, religious teachings are compatible with multiculturalism taught in Islamic educational institutions.

The studies mentioned above have not fully demonstrated the concrete strategies of Islamic religious teachers in teaching multicultural education to children in the classroom. Moreover, in the age range of children between 7-11 years old, teachers need a constructivist learning approach so that they can absorb multiculturalism material well. Therefore, this study intends to cover the academic gap, namely mapping the constructivist learning approaches and strategies carried out by teachers in instilling the values of multicultural education. 


\section{METHODS}

This qualitative research uses a case study approach. The focus of the study leads to the strategy and approach of the Akidah Akhlak teacher at MI Masalikil Huda 2 in depositing multicultural education material to students. Judging from the object, the case under study is single, namely the in-depth investigation of the application of constructivism learning (Gillham, 2007).

Data collection techniques rely on interviews, observation, and documentation. Through semi-structured interviews, the researcher met several informants consisting of 1) Head of the madrasa. He was chosen because he was considered to have the best understanding of the school structure and culture, starting from the vision, mission, goals, curriculum, institutional activities, and so on. From this, researchers want to know school policies in promoting the values of multicultural education. 2) Teacher. Researchers conducted interviews with teachers because they were executors of learning. Besides wanting to reveal the value of multicultural education that is contained in the Akidah Akhlak textbook, teachers are expected to tell the learning approaches and strategies used. 3) Students. They are learning subjects so it is important to be consulted, especially their understanding of the values of multicultural education taught by teachers.

In the observation process, the researcher observed the learning process carried out by Akidah Akhlaq teachers in the classroom but did not participate in teaching. This technique is the most important step in research, apart from interviews, because the aim is to see directly the teacher's approach and strategy in teaching. Meanwhile, the documentation technique is used by collecting information in the form of documents, such as lesson plans (RPP), school profiles, vision and mission, photos of activities, etc. which lead to the application of constructivism learning.

All data were analyzed and interpreted through four stages, namely: (1) category collection. Researchers are looking for a collection of data examples and hope to find meaning relevant to multicultural education issues that will emerge and also the way teacher learning strategies are used to embed them; (2) direct interpretation, the case study researcher looks at an example of a learning event in the classroom; (3) the researcher forms a pattern and looks for a match between two or more categories; (4) in the end, the researcher develops naturalistic generalizations through data analysis. This generalization is taken through people who can learn from a similar case (Stake, 2010). To test the credibility of the data, the triangulation technique includes the following steps: a) Comparing the results of observations in Akidah Akhlak learning with the interview data from the principal, teachers, and students, b) Comparing what is said, namely the head of the madrasa and the teacher with what the students said, c) Comparing what the informant said about the research situation through interviews with what he said all the time through observation and documentation, d) Comparing the circumstances and perspectives of the informants with the opinions and views of other informants, and e) Comparing the results of the interview to the head of the madrasa, teachers, and students with the contents of a document related to the research topic (Moleong, 2005).

\section{RESULT AND DISCUSSION}

\section{Multicultural Education Values in Akidah Akhlak Learning}

Multicultural education values in Akidah Akhlak learning class V at MI Masalikil Huda 2 Tahunan, namely:

a. Democratic Value 
The value of democracy in learning Akidah Akhlak at MI Masalikil Huda 2 Tahunan is in the form of equal opportunities for students to ask questions or express opinions. Even though each student has different backgrounds and characteristics, teachers act fairly without differentiating between one another. When discussing material about the sentences of Tayyibah and Asmaul Husna, for example, some students ask questions: "all human beings are provided with sustenance by Allah, ma'am? Are plants also given sustenance? The teacher answered, "Yes, children! Allah has the nature of Ar-Razzaq, which means the Most Providing Sustenance. So, all God's creatures must have been provided with sustenance by Allah, including animals and plants as well. That's why we must be more devoted and grateful for all that Allah has given us. It is a form of God's love for us. Allah alone loves us, so we also have to love everyone, love our friends, parents, teachers, brothers, and sisters, and so on," (observation results at MI Masalikil Huda 2 Tahunan Jepara, 22 August 2020).

Democratic values that are instilled through school culture outside the classroom. As expressed by Sri Handayani:

We embed democratic values in children, both inside and outside the classroom through the madrasa activities. In the classroom, for example, when selecting a class president. We train the children in deliberation, form a class organizational structure, and of course, the teacher or homeroom teacher also accompanies them. In the learning process, we encourage children to dare to ask questions if something is not understood. For activities outside of class, they usually carry out class meeting activities after each Semester Exam. We involve the children to be on the committee. Besides, we also have extra-curricular scouts, tambourines, and marching bands to train children's togetherness and courage (results of an interview with Sri Handayani, Head of MI Masalikil Huda 2 Tahunan Jepara, 19 August 2020).

From the results of observations and interviews above, it can be seen if the value of democracy has been implanted in MI Masalikil Huda 2 Tahun Jepara, both inside and outside the classroom. The trick is to introduce children to deliberation, togetherness, and dare to ask questions.

Based on a review of the Akidah Akhlak textbook class V MI, chapter 1 is an odd semester on the material Kalimat Tayyibah (Alhamdulillah dan Allahu Akbar) and Asmaul Husna (Ar Razzaq, Al Fattah, Asy Syakur dan Al Mughni) contains multicultural educational values in the form of a democratic attitude. The value of democracy is illustrated by the question and answer between the figure of Ade, class V MI, and an Ustaz. Ade asked the Ustaz how to get used to the tayyibah sentence in everyday life. Then Ustaz answered Ade's question (Penulis, 2018, p. 29). This can provide an example of the value of democracy. They are free to argue without any restraint. This is in line with Choirul Mahfud's view that democratic values are a comprehensive term in all forms, both cultural, political, and social justice. Every human being has the right to voice his opinion (Amin, 2018).

b. Tolerance value

In learning Akidah Akhlak, teachers teach students the importance of the value of tolerance. In this context, the value of tolerance is interpreted as an attitude of respect, accepting choices, views, beliefs, habits, and opinions of everyone even though they are different from themselves (Amin, 2018).

During the interview, Rofi'atun, class V Akidah Akhlak teacher explained:

The value of tolerance in learning can be interpreted as a value that directs respect for others, teachers, and friends. Tolerance attitude in class V learning is 
shown by the example of not making fun of friends or insulting friends who have different skin colors, physical appearance, and intelligence, extending help to others in need. For example, we as teachers provide an example of not differentiating the treatment of smart students and those who are less intelligent. Provide understanding to children that everyone has their strengths and weaknesses. Hence, we must respect our friends. Anyway, simple examples (interview result with Rofi'atun, Class V Akidah Akhlak Teacher at MI Masalikil Huda 2 Tahunan Jepara, 22 August 2020).

As a school where 100 percent of its teachers and students are Muslim, tolerance learning is still universal. For example, regarding other religious beliefs, at least it is introduced to children regarding the six religions recognized in Indonesia. The form of tolerance is to give congratulations or greetings during the holidays of other religions, such as Christmas and Vesak. All of that is okay as long as it doesn't interfere with our beliefs. "They will grow up and meet many people, maybe they are in a new environment that has differences," (results of an interview with Sri Handayani, Head of MI Masalikil Huda 2 Tahunan Jepara, 19 August 2020).

In addition to the informants above, the researcher also interviewed Siera Putri Raradhiah, one of the class V students. She said:

My friends at school and friends at home are all Muslim. Ehhh ... said the teacher, the way to respect them is by saying happy holidays to friends who are not Muslim and allowing them to carry out their respective worship. if my friends at home, have online friends who have Hinduism. If Nyepi Day, he wishes Nyepi Day to his friends. Besides, said the teacher, when we grow up we have friends of different religions, we must respect and not be hostile to them (interview results with Siera Putri Raradhiah, Class V student at MI Masalikil Huda 2 Tahunan Jepara, 24 August 2020).

Based on the results of the interview above, then MI Masalikil Huda 2 Tahunan Jepara implements learning that contains the value of tolerance by teaching students to respect other people, not to mock friends who have differences with themselves, both skin color differences, physicality, and intelligence.

Regarding tolerance for other religious beliefs, the attitude instilled in MI Masalikil Huda 2 Tahunan by providing knowledge and introduction to places of worship and understanding to students if congratulating other religious holidays is not something that is prohibited because it is a form of tolerance. All of this is done so that students will be accustomed to living a tolerant life with fellow family, relatives, neighbors, and the environment. So all of that needs to be trained from an early age.

Following interviews and observations, the researcher knows that the value of tolerance already exists in MI Masalikil Huda 2 Tahunan, and in learning Akidah Akhlaq class $\mathrm{V}$, the implementation is in the form of directing to respect and respect different views, habits, and opinions, but in terms of belief or religion it is still in a way which is simple because all teachers and students have Islam. The inculcation of the value of tolerance is still in the form of basic knowledge, has not shown tolerance for differences in beliefs more specifically because it has not directly interacted with those who have different beliefs and religions.

The above goes hand in hand with the material Adab Bertetangga dan Bermasyarakat (Neighbors and Community Ethics) which has accommodated tolerance. In the textbook, it is written that a neighbor is a person whose house is close to our house. Everyone whose house is adjacent to our house is a neighbor, whether Muslim or not. We must uphold tolerance for neighbors (Penulis, 2018, p. 32). He also 
explained that in our neighbors we must advise each other, help each other, and work together, protect each other, love each other, respect each other, and be polite (Penulis, 2018, pp. 37-38). Similar material is also seen in the section Masyarakat dan Adab (Society and Ethics) (Penulis, 2018).

c. Kinship or Brotherly Value

The value of kinship is an attitude of kinship, friendship, which generally arises from a sense of brotherhood or belonging to a group. With a sense of kinship, then there will be a sense of solidarity, brotherhood with various ethnic groups, ethnic groups, and religions (Mahfud, 2010). In the learning process at MI Masalikil Huda 2, there is a value of kinship or brotherhood, namely in the form of affection, empathy, and mutual respect between teachers and students. This can be seen from the results of observations made by researchers in class V. At the beginning of the lesson, the teacher greets students and asks about the students' news and health. In the middle of learning, it turned out that there were students who did not bring pens. Then the teacher lent the students so they could go back to working on the questions. There is also one student who forgot to bring a textbook. Then borrowed by his classmate to read together. On that occasion, the teacher reminded and advised students gently when class conditions began to get rowdy (observation results at MI Masalikil Huda 2 Tahunan Jepara, 22 August 2020).

The head of the madrasa conveyed this to the researcher during an interview in his room, "To foster empathy in children, we usually teach students to visit friends who are sick accompanied by a teacher or homeroom teacher. Usually, they take funds from the class treasury," (interview results with Sri Handayani, Head of MI Masalikil Huda 2 Tahunan Jepara, 19 August 2020). This was confirmed by the narrative of one student, "I once lent pocket money to my friend. I left his pocket money at home. It's a pity if you don't snack, my friends and I also like to do homework together so we don't forget and can ask friends," (interview results with Siera Putri Raradhiah, Class V student at MI Masalikil Huda 2 Annual Jepara, 24 August 2020).

The value of kinship or brotherhood in Asmaul Husna material, namely nature Ar-Razzaq, Al-Fattah, Asy-Syakur and Al-Mughni). Al-Fattah means that Allah is the one who opens mercy to all of His creatures. Allah SWT gives mercy or compassion to all creatures, especially animate creatures. People who do not have faith are loved by Allah. For example: how many people do not have faith in Him, but their efforts are successful and get great profits. This indicates that the door to Allah's love is open to anyone as long as they are active in their efforts (Penulis, 2018). The material about the value of brotherhood also contains topics Dermawan (Generous). In these materials, we are required to uphold a tolerant attitude with our neighbors. Please help in the obligatory goodness of the law. Moreover, please help with the neighbors (Penulis, 2018).

From the observations and interviews above, the researchers concluded that the kinship value implemented by the MI Masalikil Huda 2 Annual Jepara teacher was quite effective. They teach students about a sense of brotherhood, solidarity with their friends, and teach them to love all people, whether from different religions and ethnicities. This is under the theory described above that with the value of kinship or brotherhood there will be a sense of solidarity, a sense of brotherhood with various ethnic groups, ethnicities, groups, and religions, and understanding the meaning of differences. It's just that, in learning Akidah Akhlak, teachers have not linked a sense of brotherhood with ethnicity and class. Though this aspect is also important. Because, as 
we know, Indonesia has various ethnic groups and groups that need to be introduced to children.

d. Equality or equivalence Value

In the Akidah Akhlak learning process, all students have the same position in front of the teacher. There is no special treatment or differentiation between one student and another. Male or female students have the same opportunities, rights, and obligations. Even though institutionally it is under the coordination of the Ministry of Religion of the Republic of Indonesia, there is no class separation between students and sides (observation results at MI Masalikil Huda 2 Tahunan Jepara, 29 August 2020). This was confirmed by the statement of one of the teachers who was the research informant:

We do not differentiate between gender. Whether women or men, we consider that they have the same rights and obligations. In our class, we do not differentiate between the social or economic status of children, whether their children are rich or not. Incidentally, in my class, there are teachers' children, but in the learning process, I still consider them the same (interview result with Rofi'atun, Class V Akidah Akhlak Teacher at MI Masalikil Huda 2 Tahunan Jepara, 29 August 2020).

In extracurricular activities, all students have the same rights and obligations. It doesn't matter whether he is of high or low social or economic status. Is the child good academically or not. All children have the same right to do extra activities at school. For example, every child may participate in scouts, marching band, tambourine, or other arts.

We also carry out routine activities every morning, namely reading Asmaul Husna and daily prayers led by student representatives through speakers from the office. We ask two people every day in turn. This trains courage and indirectly shows equal rights for every child (interview with Sri Handayani, Head of MI Masalikil Huda 2 Tahunan Jepara, 19 August 2020).

In the Akidah Akhlak textbook, the value of equality is described with a description that all deeds or good deeds will receive a reward from Allah in the form of heaven. Meanwhile, bad deeds will be rewarded in the form of hell's torment. Allah is the Most Just Essence who will weigh human deeds as fairly as possible, so that no one feels disadvantaged, even though it is only as heavy as the weight of his deeds (Penulis, 2018, pp. 36-38). This opens our eyes that all human beings have the same position, rights, and obligations before Allah. The end of human success is not seen from the abundance of wealth, high position, intelligence, beauty, and various other forms of material excellence. It is precisely what determines our submission to Allah. The similarity value is also shown in the material Akhlak Terpuji (Commendable Moral) be optimistic. Basically, everyone has the same potential. So, you must be optimistic about studying, worshiping, and working in order to achieve your goals and get a better life by being serious about achieving them.

\section{Constructivism Learning Strategy}

In the process of learning Akidah Akhlak, teachers use various approaches. Among these include historical approaches, gender perspectives, and aesthetics. The historical approach appears when the teacher explains the subject matter while inviting students to review events that have happened before. This is done so that students have a real frame of mind which is then linked between the present or the future. As stated by Rofi'atun as follows: 
The teacher relates the ethics of neighbors and society that existed at the time of the Prophet with the present era. Comparing how the condition of the community and neighbors used to be with now so that the good side can be taken to be applied today (interview result with Rofi'atun, Class V Akidah Akhlak Teacher at MI Masalikil Huda 2 Tahunan Jepara, 29 August 2020).

The gender perspective approach is seen when teachers do not differentiate between men and women. Because everyone has the same opportunities, rights, and obligations. The teacher ignores the gender of the learners. In the delivery of the material, there is no difference between men and women. The learning activities are the same. Every child has the same opportunity to ask questions or express opinions. However, sometimes girls are more subtle and obedient. Whereas for boys, teachers are a little more assertive (observations in Class V MI Masalikil Huda 2 Tahunan, 22 August 2020).

The aesthetic approach teaches and provides an overview of the beautiful, friendly, peaceful, polite, and polite ways of learning so that the teacher's delivery of material to students is not rigid. The teacher applies an aesthetic approach in delivering the Akidah Akhlak material in class. It can be seen from the teacher's friendly teaching style, using polite language and attitude, sometimes also interspersed with Javanese manners. This was admitted by one of the students when met by the researcher, "The teaching method is fun, not fun, sometimes the teacher also jokes around, so it doesn't make the classroom atmosphere tense. Unless there are stubborn friends. Teachers are usually more assertive," (interview results with Siera Putri Raradhiah, Class V student at MI Masalikil Huda 2 Tahunan Jepara, 24 August 2020).

a. Cooperative learning strategies

One of the strategies used in learning is cooperative learning, which is essentially cooperative learning. The teacher tries to teach the children to be active by doing activities together. This can practice tolerance, democracy, kinship, equality, and unity. Also, this strategy is oriented towards creating a two-way learning climate between students and teachers. The teacher uses collective learning methods such as question and answer, discussion, talking sticks, and snowball throwing. The point is, as much as possible to make the class active and interesting even with the makeshift learning media. The teacher directs students to interact with each other in school activities. For example, istighosah (pray) routine activities, scout extracurricular activities, filling in wall magazines, and cooperation activities cleaning schools (observations at MI Masalikil Huda 2 Tahunan, 19 August 2020).

With joint learning activities, it can train children to respect each other, respect differences, practice democratic attitudes, tolerance, unity, brotherhood, and empathy with others. We divided the children into group assignments. Usually, it is mixed between boys and girls, between those who are smart and those who are less intelligent to not differentiate between them. For cooperation (interview result with Rofi'atun, Class V Akidah Akhlak Teacher at MI Masalikil Huda 2 Tahunan Jepara, 22 August 2020).

b. Concept achievement strategy

Students are invited to visit locations that show the diversity of regional crafts and cultures. This is to show children directly the natural phenomenon of diversity in the environment. The goal is to practice tolerance and respect for differences.

Through outing class activities, after the Mid-Semester Examination or Final Semester Examination, the teacher introduces the local crafts and culture in Jepara to children. Children were brought to the Troso weaving center. They see the weaving 
production process of traditional craftsmen. Have also seen a pottery center in Mayong. Children joined the practice of making pottery. Likewise with their visit to Kriyan to find out about the process of making monel (the art of handicrafts from silver) Jepara. In between these processes, the teacher, while inserting knowledge to the children, that all around us there are various kinds of crafts. Every difference is normal, so it must be respected and respected.

Figure 1 Concept Achievement Strategy through Pottery Making

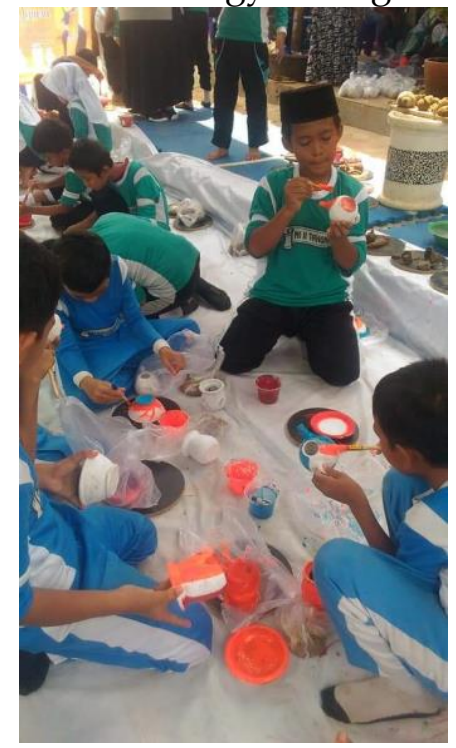

\section{c. Exemplary Strategies}

With an exemplary strategy, multicultural values can be directly accepted and emulated by children. The teacher not only delivers theoretical subject matter orally but is directly exemplified in attitudes and actions. For example, to increase the sense of brotherhood and affection, every morning a shaking (mushafahah) is held between the teacher and the students. Inside, the teacher provides an example by respecting all students without discriminating against their academic achievement. The teacher also provides practical examples of please help. Like lending a pen or a book if there are students who do not bring along, visiting a sick friend (observation results at MI Masalikil Huda 2 Tahunan, 29 August 2020).

d. Habitual strategy

With the habituation strategy, the teacher emphasizes to the students the meaning of diversity and the nature of differences. If differences are certain in human life, then differences are the destiny of Allah which cannot be avoided. The differences exist not to divide, but to complement and coexist. As social beings, humans cannot live alone because they need the existence of other people.

We teach children to respect the differences between themselves and their friends. For example, don't make fun of friends who have black skin. Must help with friends, help clean the class according to the picket schedule. We include the understanding that if Allah created everything differently, something different is the destiny of Allah, then we must respect and tolerate the differences that exist. Some people are Muslim, Christian; some people are rich or poor, some people have white or black skin. As much as possible convey it to 
students simply and interestingly (interview result with Rofi'atun, Class V Akidah Akhlak Teacher at MI Masalikil Huda 2 Tahunan Jepara, 29 August 2020).

e. Role-playing learning strategies

Role-playing is a learning strategy to solve problems related to social phenomena (Sanjaya, 2007). This strategy is enough to attract children to be active in the learning process. Children can also better appreciate and understand the material being taught. "Classes can be more lively, but you have to be more patient because the class will be crowded and if you want to use this method you have to adapt it to the material," (interview with Rofi'atun, Akidah Akhlak Class V MI Masalikil Huda 2 Tahunan Jepara, 29 August 2020). On the occasion of classroom observation, the researcher observed the Akidah Akhlak learning process through role-playing strategies. At that time, the material taught by the teacher was the takziyah chapter. The teacher divides the roles of several male and female students. Some play the role of disaster recipient families, travelers, and religious leaders. As is commonly practiced by the community, students carry out their respective roles neatly. At the end of the lesson, the teacher again emphasized the importance of takziyah (empathy for someone's death). Besides being a form of solidarity between fellow Muslims, takziyah is proof of our love for our neighbors.

From the explanation above, at least two main findings were made in this study. First, the madrasa as Islamic educational institutions in Indonesia is still consistent in teaching multicultural educational values such as democracy, tolerance, brotherhood, and equality. In this case, these values are contained in the Akidah Akhlak learning material. Second, the madrasa teachers have good pedagogical skills. The proof, through constructivism learning strategies, namely cooperative learning, concept achievement, exemplary. habituation, and role-playing, the teacher can anchor the material values of multicultural education to students. This finding has theoretical implications, namely affirming the function of the madrasa as Islamic educational institutions that spread moderate Islamic teachings in Indonesia through the values of multicultural education.

The first findings in this research also refute the theoretical claims of previous research that accuse the madrasa of dysfunction; from inclusive, tolerant, and moderate to exclusive, intolerant, and extreme. It is undeniable that a small proportion of the madrasa in Indonesia have been coopted by the influence of the transnational Islamic movement as a logical consequence of the global Muslim geopolitical dynamics. The ideal Islam according to them is to return to the values of salaf al-salih by totally surrendering to the literal meanings of the Qur'an and sunnah (Noor et al., 2020). It did not stop there, Islamic groups who later identified themselves as Salafis, then ignored the local traditional values and cultural diversity that had taken root in Indonesian soil. But once again, in terms of quantity, the madrasa affiliated with Salafi groups are far less numerous than the madrasa under moderate Islamic organizations such as NU and Muhammadiyah. From a juridical perspective, Salafi the madrasa that has been legally proven to be affiliated with transnational Islamic movements such as Hizbut Tahrir, for example, will surely be dissolved by the Indonesian government. This is because these organizations fall into the category of prohibited organizations.

Whereas the second finding in this study dismissed the assumption of previous scholars who proposed a thesis that the madrasa teachers were unable to promote the value of multicultural education (Raihani, 2018). Through constructivist learning strategies, the teacher has succeeded in proving that students' knowledge is dynamically constructed through active interaction with the world around them as 
well as Piaget's famous postulate (Csizmadia et al., 2019). The inclusive characteristics taught by the madrasa teachers in Indonesia have a distinctive style if they are matched with the phenomenon of madrasas in other Muslim countries, for example, Afghanistan and India. There, the madrasa is indicated to be involved in the indoctrination of a fundamentalist Islamic ideology that destroys the nuances of communal peace (Alam, 2011).

\section{CONCLUSION}

The values of multicultural education contained in learning Akidah Akhlak class $\mathrm{V}$ at MI Masalikil Huda 2 Tahunan include the values of democracy, tolerance, the value of equality or equality, the value of brotherhood or kinship, and the value of unity. To implement these values in learning, teachers make use of two important aspects, namely aspects of the approach and strategy. The strategy used is cooperative learning, conceptual achievement, modeling, habituation, and role-playing. While the approach was chosen is to use a historical approach, a gender perspective approach, and an aesthetic approach. Supporting factors in the implementation of multicultural education values in learning Akidah Akhlak class V MI Masalikil Huda 2 Tahunan, namely school climate, the role of teachers, and interactions between components, as well as school programs and activities. While the inhibiting factors are the limited school facilities and infrastructure and the lack of learning media.

\section{ACKNOWLEDGEMENT}

The completion of this research would be impossible without the contributions of various parties. So, I will use this opportunity to give thanks as a form of deep appreciation for them. First, researchers need to thank the community of UIN Sunan Kalijaga Yogyakarta, especially the postgraduate lecturers of the Islamic Studies Doctoral Program. Thanks to them, the research instincts of researchers are always stimulated. Second, the Institute for Research and Community Service of the Islamic University of Nahdlatul Ulama (Unisnu) Jepara, which never tires of motivating writers to carry out research activities. Third, the researchers are indebted to the MI Masalikil Huda 2 Tahunan community who has been willing to be used as research locations. May their kindness be rewarded by Allah.

\section{AUTHOR CONTRIBUTION STATEMENT}

AS (Ahmad Saefudin) is the lead author in this study review. $\mathrm{R}$ becomes the second writer who guides and directs the main writer. Meanwhile, DS is the third author who assists the main author in collecting field research data.

\section{REFERENCES}

Alam, A. (2011). Inside a Madrasa: Knowledge, Power and Islamic Identity in India. In Inside a Madrasa. https:/ / doi.org/10.4324/9780367818081

Amin, M. (2018). Pendidikan Multikultural. PILAR, 9(1). Google Scholar

Csizmadia, A., Standl, B., \& Waite, J. (2019). Integrating the Constructionist Learning Theory with Computational Thinking Classroom Activities. Informatics in Education, 18(1), 41-67. https://doi.org/10.15388/infedu.2019.03

DomNwachukwu, C. S. (2010). An Introduction to Multicultural Education: from Theory to Practice. United Kingdom: Rowman \& Littlefield Publishers, Inc. Google Scholar

Evans, F. (1995). Multiculturalism: Examining the Politics of Recognition. In Multiculturalism: Examining the Politics of Recognition (Vol. 11). 
https://doi.org/10.5840/radphilrevbooks199511/1211

Gillham, B. (2007). Case Study Research Methods. Bloomsbury Publishing. Google Scholar

Grant, C. A., \& Lei, J. L. (Eds.). (2001). Global Constructions Of Multicultural Education: Theories and Realities. Routledge. Google Scholar

Haddock, B., \& Sutch, P. (2003). Multiculturalism, Identity, and Rights. https:// doi.org/10.4324/9780203563250

Ismail, F. (1995). Islam, Politics, and Ideology in Indonesia: a Study of The Process of Muslim Acceptance of the Pancasila. McGill University Libraries.

Jiyanto, \& Efendi, A. E. (2016). Implementasi Pendidikan Multikultural di Madrasah Inklusi Madrasah Aliyah Negeri Maguwoharjo Yogyakarta. Jurnal Penelitian, 10(1), 25-44. Google Scholar

Kivisto, P. (2008). Multiculturalism in a global society. John Wiley \& Sons. Google Scholar Kymlicka, W. (2020). Multicultural citizenship (pp. 270-280). Routledge. Google Scholar

Mahfud, C. (2010). Pendidikan Multikultural. Yogyakarta: Pustaka Pelajar.

Máiz, R., \& Requejo, F. (2004). Democracy, Nationalism and Multiculturalism. https:// doi.org/10.4324/9780203313923

Maryati, K. (2006). Sosiologi:-Jilid 2. ESIS. Google Scholar

May, S. (2009). Critical multiculturalism and education. The Routledge international companion to multicultural education, 33-48. Google Scholar

Moleong, L. J. (2005). Metodologi Peneltian Kualititaif. Bandung: Remaja Rosda Karya. Google Scholar

Noor, F. A., van Bruinessen, M., \& Sikand, Y. (2008). The madrasa in Asia: Political activism and transnational linkages (p. 304). Amsterdam University Press. Google Scholar

Parekh, B. (2000). Rethinking Multiculturalism: Cultural Diversity and Political Theory. https:// doi.org/10.1086/jop.64.1.2691679

Penulis, T. (2018). Modul PAI dan Bahasa Arab untuk MI. Jepara: LP Ma'arif NU Jepara.

Piaget, J., \& Valsinen, J. (2017). The Child's Conception Of Physical Causality. Routledge. Google Scholar

Piaget, J. (2013). The construction of reality in the child (Vol. 82). Routledge. Google Scholar

Piaget, J. (2003). The Psychology Of Intelligence. Routledge. Google Scholar

Pritchard, A. (2008). Ways of Learning: Learning Theories and Learning Styles in The Classroom. In The Lancet. https:/ / doi.org/10.1016/S0140-6736(45)91319-5

Raihani, R. (2018). Education for Multicultural Citizens in Indonesia: Policies and Practices. Compare: A Journal of Comparative and International Education, 48(6), 9921009. https:/ / doi.org/10.1080/03057925.2017.1399250

Sahlan, A. (2014). Enhancement of Culture in Education: Research on Indonesian High School. Procedia - Social and Behavioral Sciences, 143(1), 117-121. https:// doi.org/10.1016/j.sbspro.2014.07.371

Sanjaya, W. (2007). Strategi Pembelajaran Berorientasi Standar Proses Pendidikan. Jakarta: Kencana Prenada Media Group. Google Scholar

Seymour, R., \& Turner, S. (2002). Otonomi Daerah: Indonesia's Decentralisation Experiment. New Zealand Journal of Asian Studies, 4(2), 33-51. Google Scholar

Stake, R. E. (2010). Qualitative Research: Studying How Things Work. Google Scholar

Soutphommasane, T. (2005). Grounding multicultural citizenship: From minority rights to civic pluralism. Journal of Intercultural Studies, 26(4), 401-416. https:// doi.org/10.1080/07256860500270239 
Zulaeha, I. (2013). Innovation Models of Indonesian Learning in Multicultural Society. Procedia - Social and Behavioral Sciences, 103, 506-514. https:// doi.org/10.1016/j.sbspro.2013.10.367

\section{Copyright Holder :}

(C) Hermawan, E., \& Arifin, A., (2021).

First Publication Right :

(C) Jurnal Iqra' : Kajian Ilmu Pendidikan

This article is under

(ㄷ)(1) (2) 